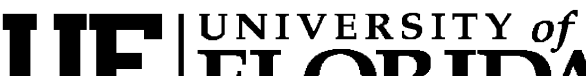 FLORIDA \\ IFAS Extension
}

\section{Recognizing Florida's Venomous Snakes ${ }^{1}$}

Steve A. Johnson and Martin B. Main ${ }^{2}$

Florida is home to 45 species of native snakes, six of which are venomous (poisonous). The venomous species include five pit vipers (Eastern Diamond-backed Rattlesnake, Timber Rattlesnake, Pygmy Rattlesnake, Copperhead, and Cottonmouth) and the Coral Snake. Copperheads and Timber Rattlesnakes have a limited range in Florida. Copperheads only occur in a small area of Florida's Panhandle just west of Tallahassee, and Timber Rattlesnakes are only found in northern Florida as far south as Gainesville and in limited portions of the Panhandle. The other four venomous species are found throughout the state. Florida's venomous snakes occur in a variety of natural habitats, ranging from swamps to dry woods.

The five species of pit vipers all share several characteristics. The pupils of their eyes are vertical (cat-like) and they have a deep facial pit between each eye and nostril. These characteristics can be difficult to see unless a snake is examined closely, so do not rely on them to differentiate venomous from non-venomous species. Florida's pit vipers have blocky, triangular-shaped heads that are distinctly broader than their necks. Relative to their length, these species are heavy-bodied snakes.

Although each of the six venomous species in Florida have unique characteristics that allow them to be readily identified by experts, there are many non-venomous species with which the venomous species may be confused. Therefore it is best not to attempt to capture, harass, or harm any snake. To do so may put you at risk of being bitten by a venomous species.

\section{Cottonmouth/Water Moccasin}

The Cottonmouth is the most aquatic of Florida's venomous snakes and occurs throughout the state (Figure 1). Although they may exceed five feet in length, most adult Cottonmouths observed in Florida are about three feet long. This species prefers the margins of lakes, rivers, and wetlands. Adults are dark-colored and may have a faint crossband pattern or be a uniform black. The eye is camouflaged by a broad, dark facial stripe that runs from the eye to the back of the head.

1. This document is WEC 202, one portion of a 4-part package of the Department of Wildlife Ecology and Conservation entitled "Dealing with Venomous Snakes in Florida School Yards." Institute of Food and Agricultural Sciences (IFAS), University of Florida. First published: September 2005. Please visit the EDIS Web site at http://edis.ifas.ufl.edu. Accompanying documents are available by contacting Steve A. Johnson (johnsons@wec.ufl.edu) or Martin B. Main (mbma@mail.ifas.ufl.edu). A free PowerPoint presentation (with speaking notes) about venomous snakes in Florida is available upon request from Steve A. Johnson.

2. Steve A. Johnson, Assistant Professor and Extension Specialist, Department of Wildlife Ecology and Conservation, Mid-Florida Research and Education Center, University of Florida's Plant City Campus, 33563; Martin B. Main, Associate Professor and Extension Wildlife Specialist, Department of Wildlife Ecology and Conservation, Southwest Florida Research and Education Center, Institute of Food and Agricultural Sciences, University of Florida, Immokalee, FL 34142.

The Institute of Food and Agricultural Sciences (IFAS) is an Equal Opportunity Institution authorized to provide research, educational information and other services only to individuals and institutions that function with non-discrimination with respect to race, creed, color, religion, age, disability, sex, sexual orientation, marital status, national origin, political opinions or affiliations. U.S. Department of Agriculture, Cooperative Extension Service, University of Florida, IFAS, Florida A. \& M. University Cooperative Extension Program, and Boards of County Commissioners Cooperating. Larry Arrington, Dean 


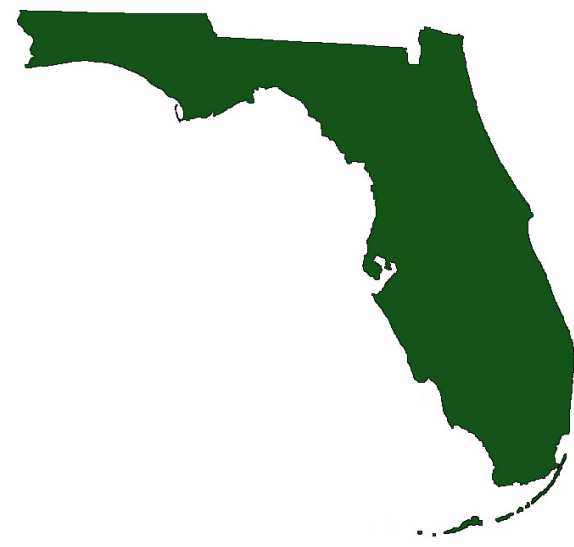

Figure 1. Florida distribution of the Cottonmouth: Entire state

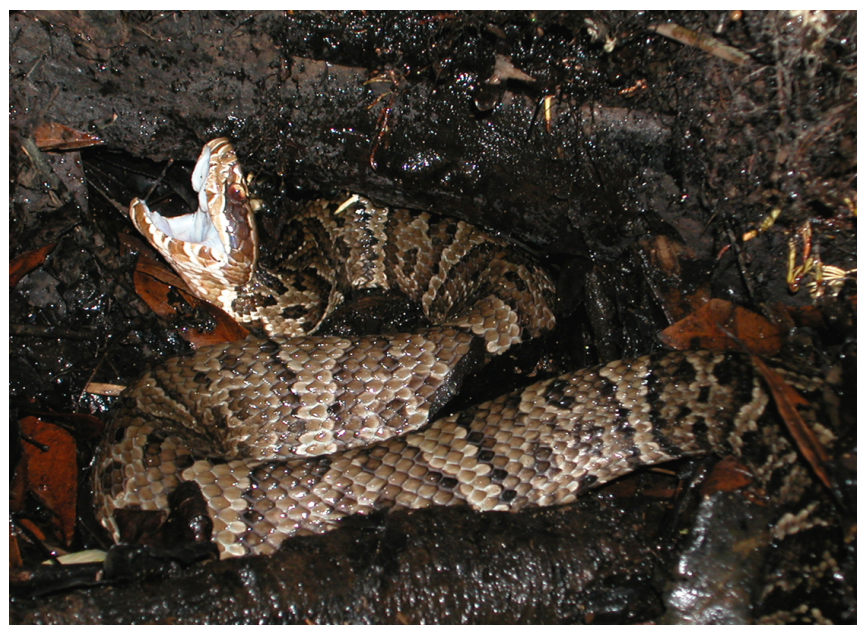

Figure 2. Adult Cottonmouth exhibiting mouth-gaping behavior. Credits: Steve A. Johnson, University of Florida

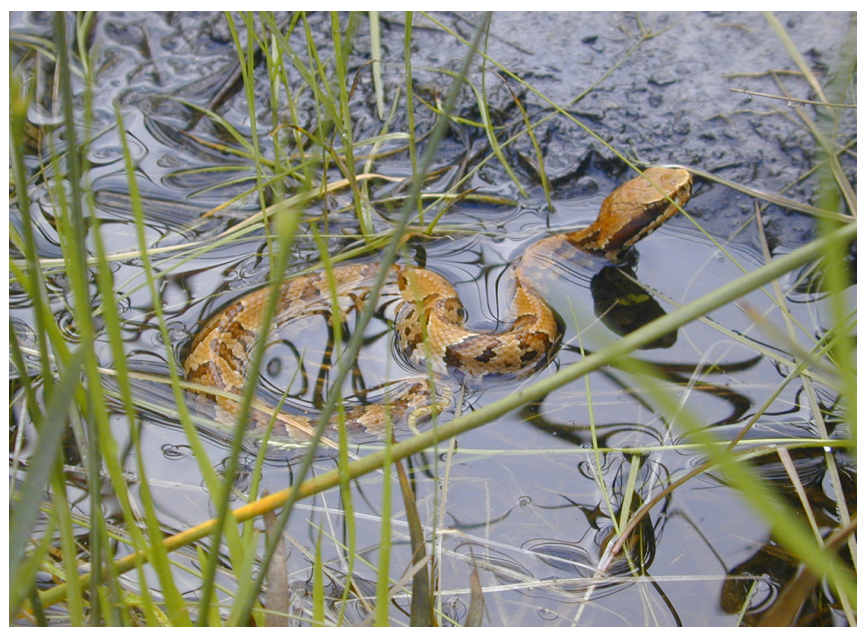

Figure 3. Juvenile Cottonmouth. Credits: Steve A. Johnson, U.S. Geological Survey

As a defensive response when threatened, Cottonmouths often will open their mouths wide, revealing the cotton-white interior (Figure 2). Young Cottonmouths (Figure 3) are brightly colored with reddish-brown crossbands and a yellow-colored tail. When young they look very similar to the Copperhead.

Several species of harmless water snakes are often mistaken as Cottonmouths. Water snakes are not venomous but they tend to be aggressive and quick to bite. To avoid confusion and the potential for being bitten, it is best to leave all water snakes alone.

\section{Copperhead}

In Florida, Copperheads only occur in a small area of Florida's Panhandle just west of Tallahassee, primarily along the Apalachicola River and its tributaries (Figure 4).

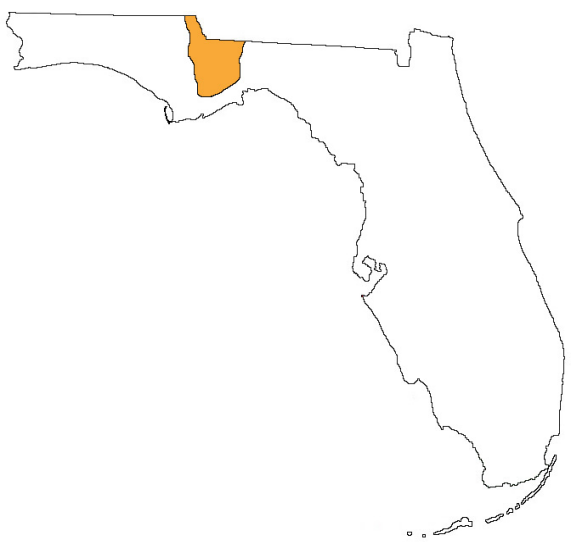

Figure 4. Florida distribution of the Copperhead: Small part of the Panhandle

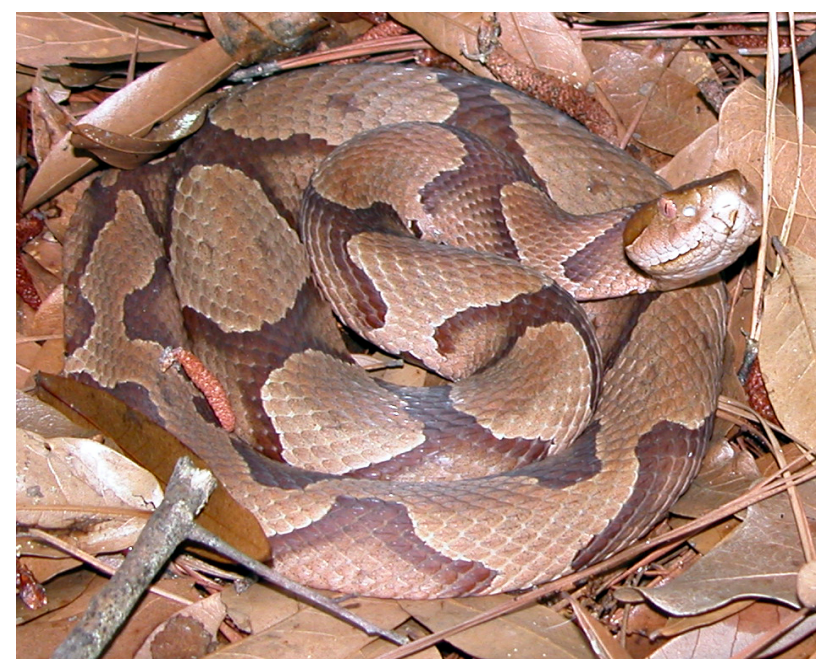

Figure 5. Copperhead. Credits: William J. Barichivich, U.S. Geological Survey 
Copperheads prefer to remain near streams and wet areas. A full grown Copperhead is usually less than three feet long. Copperheads are relatively thick-bodied with bold markings (Figure 5). The general body color of these snakes is light brown to gray, and there are large bands of darker brown along their backs. Because of constrictions in the darker bands along the center of the back of this species, the darker bands have an hourglass shape. The alternating pattern of lighter and darker bands provides Copperheads with exceptional camouflage in the forested areas where they live. Young Copperheads look very similar to adults except the tips of their tails are yellowish in color.

\section{Eastern Diamond-backed Rattlesnake}

This is a very dangerous snake and should not be approached. The Eastern Diamond-backed Rattlesnake is Florida's largest venomous snake and may exceed six feet in length. It occurs throughout Florida in a variety of dry habitats, such as pinelands, scrub, and golf courses (Figure 6).

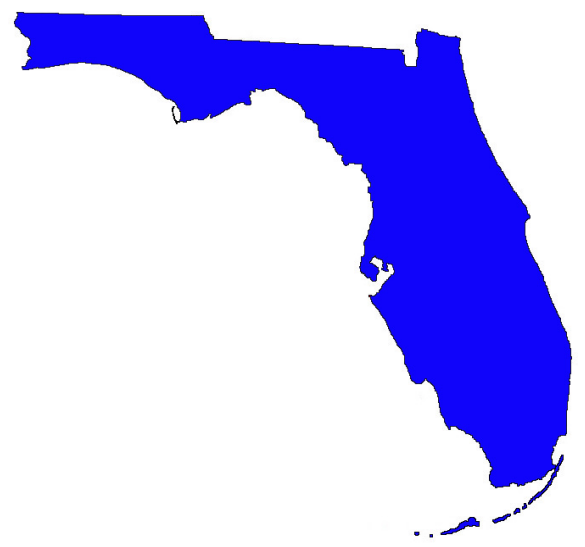

Figure 6. Florida distribution of the Eastern Diamond-backed Rattlesnake: Entire state

Eastern Diamond-backed Rattlesnakes have bold markings down their backs that include a row of large, dark diamonds with brown centers and cream-colored borders (Figure 7). The tail ends in a rattle that is used to make a loud buzzing sound when the snake feels threatened. Some individuals may not rattle, even when they are poised to strike. The large, thick head has a light-bordered, dark stripe running diagonally through the eye to the rear of the jaw. The scales of this species are strongly keeled (i.e., there is

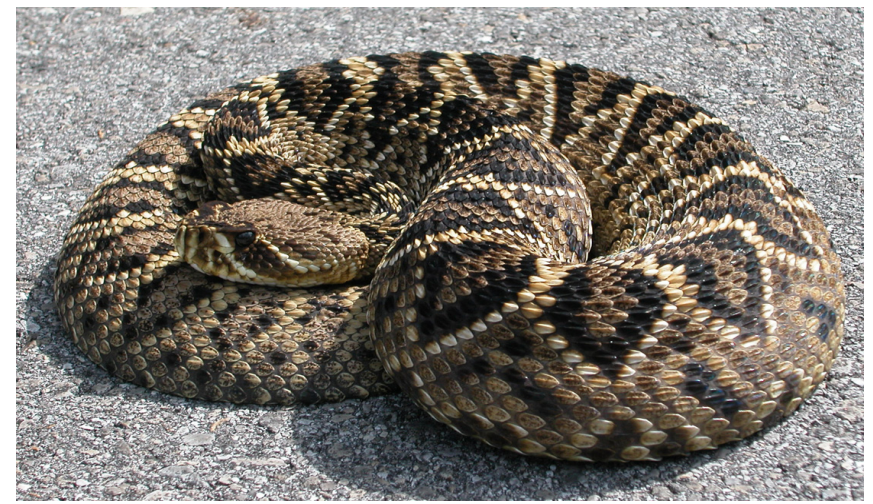

Figure 7. Eastern-diamondbacked Rattlesnake. Credits: Steve A. Johnson, U.S. Geological Survey

a ridge along the center of each scale), giving these snakes a rough appearance. The young are similar to adults in color pattern.

\section{Timber Rattlesnake}

The Timber Rattlesnake (a.k.a. Canebrake Rattlesnake) has a relatively small range in the state; it is only found in northern Florida as far south as Gainesville and in limited portions of the Panhandle (Figure 8).

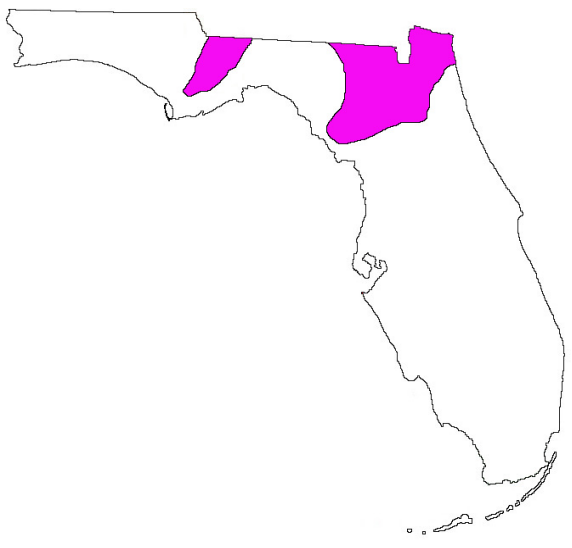

Figure 8. Florida distribution of the Timber Rattlesnake: Small part of the Panhandle and northern Florida

This species prefers moist pinelands, river bottomlands, and hammocks. Timber Rattlesnakes can grow to five feet or longer. These snakes have a pinkish-gray to tan body color with prominent, irregularly-shaped, dark marks and bands (Figure 9). A reddish-brown stripe runs along the middle of the back of Timber Rattlesnakes.

The tail of the species is dark brown or black and ends with a large rattle. Timber Rattlesnakes have large, thick heads and there may be a band running 


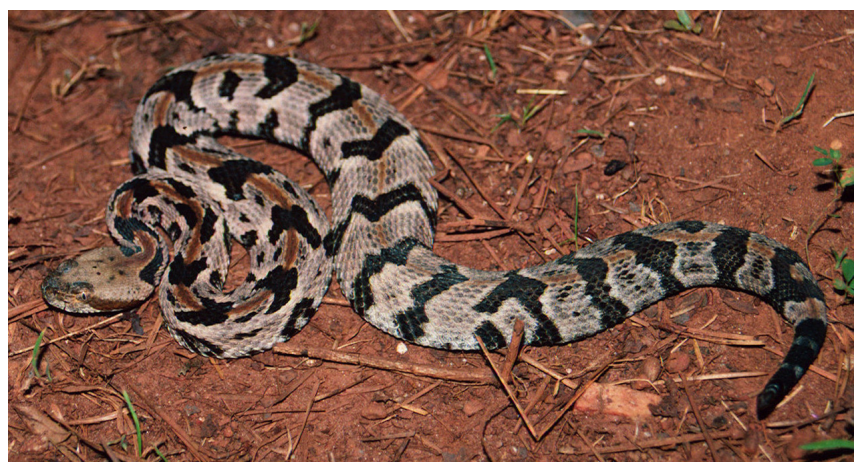

Figure 9. Timber Rattlesnake. Credits: John Jensen, Georgia Department of Natural Resources

from each eye to the rear of the head. The scales of this species are strongly keeled, giving these snakes a rough appearance. The young are similar to adults in color pattern.

\section{Pygmy Rattlesnake}

Pygmy Rattlesnakes are the smallest of Florida's venomous snake species. Adults rarely exceed 20 inches in length. Pygmy Rattlesnakes range throughout the state and occur in many different habitats that include pine flatwoods, oak scrub, open pinelands, and palm hammocks (Figure 10).

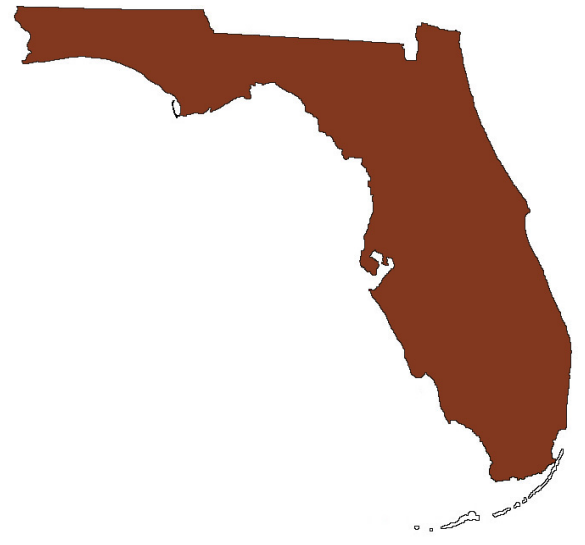

Figure 10. Florida distribution of the Pygmy Rattlesnake: Entire state except for the Keys

This is one of the most commonly encountered venomous snakes that occasionally is found in residential neighborhoods. Pygmy Rattlesnakes have a dark band that runs from each eye to the rear of the jaw (Figure 11). Their bodies are covered with numerous dark blotches with a row of darker blotches running down the middle of the snake's back. Usually a series of reddish-brown marks can be seen between the blotches on the back.

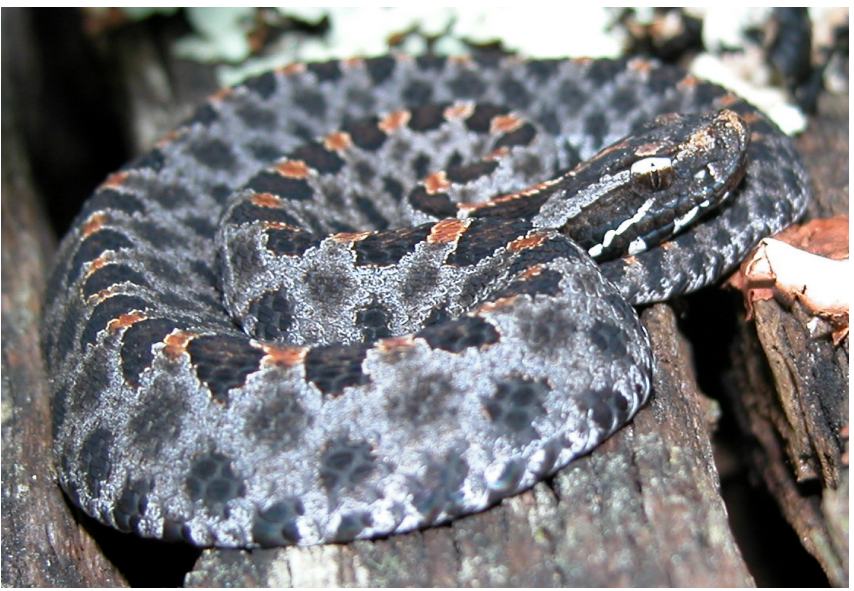

Figure 11. Pygmy Rattlesnake. Credits: Steve A. Johnson, U.S. Geological Survey

The rattle on the tip of the tail of this species is so small that it cannot be heard even when shaken vigorously by the snake. Pygmy Rattlesnakes are bold and will often hold their ground if approached. They will bob their head and strike into the air if they feel threatened.

\section{Coral Snake}

Coral Snakes occur in many types of habitats throughout the state (Figure 12) but are seldom encountered because they are quite secretive and spend much of their lives underground.

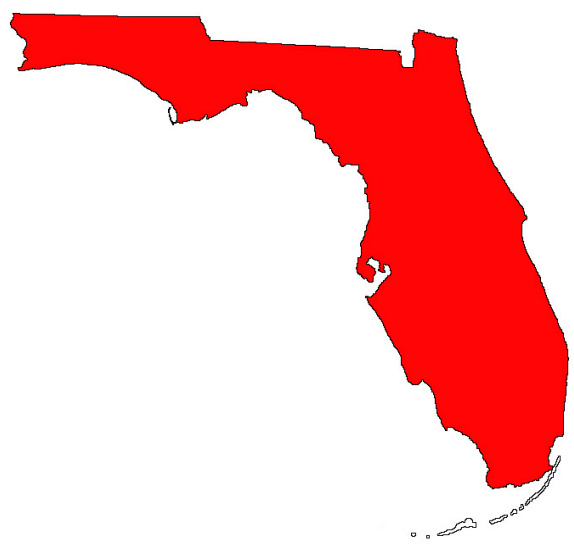

Figure 12. Florida distribution of the Coral Snake: Entire state except for the Keys

They are rarely longer than 30 inches and are usually no bigger around than a quarter. Coral Snakes are identified by the alternating bands of black, yellow, and red that give this species its bold appearance (Figure 13). 
Two non-venomous species (Figures 14 and 15) look very similar to Coral Snakes because they also have bands of red, black, and yellow (or orange or white). However, the arrangement of the bands differs between the non-venomous species (Scarlet Kingsnake and Scarlet Snake) and the Coral Snake. In the two non-venomous species the red bands touch only black bands, but in Coral Snakes the red bands only touch yellow bands. Remember the stoplight phrase "yellow, red, STOP!" If the red and yellow bands are next to each other, like the colors of a stoplight, it is a Coral Snake. Another feature of the Coral Snake is its blunt, black snout, which is followed by a band of yellow on the head. Neither the Scarlet Kingsnake nor the Scarlet Snake have black snouts.

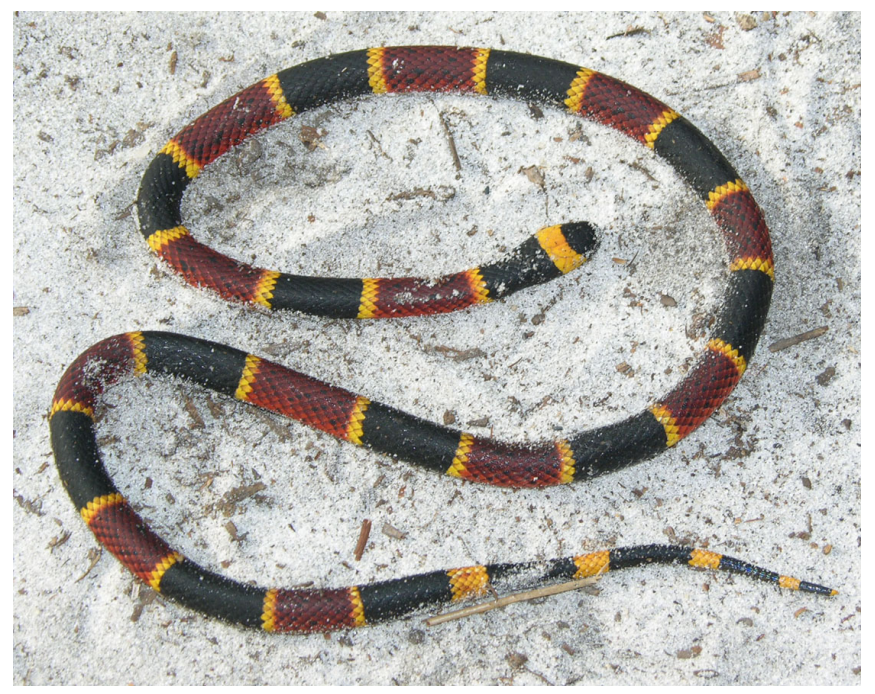

Figure 13. Coral Snake (venomous). Credits: Steve A. Johnson, University of Florida
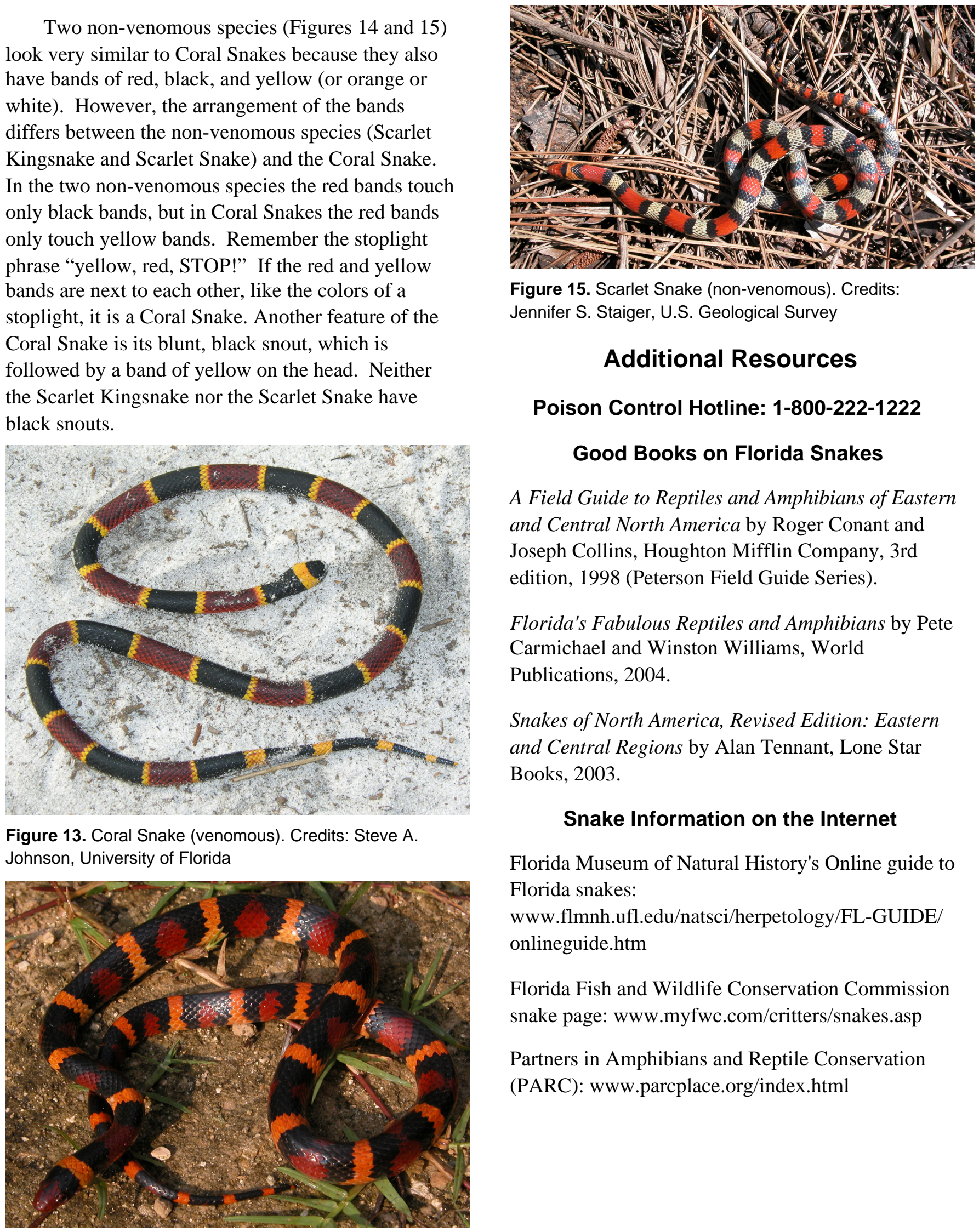

Figure 15. Scarlet Snake (non-venomous). Credits: Jennifer S. Staiger, U.S. Geological Survey

\section{Additional Resources}

\section{Poison Control Hotline: 1-800-222-1222}

\section{Good Books on Florida Snakes}

\section{A Field Guide to Reptiles and Amphibians of Eastern and Central North America by Roger Conant and Joseph Collins, Houghton Mifflin Company, 3rd edition, 1998 (Peterson Field Guide Series).}

Florida's Fabulous Reptiles and Amphibians by Pete Carmichael and Winston Williams, World Publications, 2004.

Snakes of North America, Revised Edition: Eastern and Central Regions by Alan Tennant, Lone Star Books, 2003.

\section{Snake Information on the Internet}

Florida Museum of Natural History's Online guide to Florida snakes:

www.flmnh.ufl.edu/natsci/herpetology/FL-GUIDE/ onlineguide.htm

Florida Fish and Wildlife Conservation Commission snake page: www.myfwc.com/critters/snakes.asp Partners in Amphibians and Reptile Conservation (PARC): www.parcplace.org/index.html

Figure 14. Scarlet Kingsnake (non-venomous). Credits: William J. Barichivich, U.S. Geological Survey 